\title{
Pengembangan Bahan Ajar E-Book Akuntansi Keuangan Kelas XII SMK pada Materi Aset Tetap Berwujud Berbasis Pendekatan Saintifik
}

\author{
Fahira Qotrunnada \\ e-mail: fahira.17080304082@mhs.unesa.ac.id \\ Joni Susilowibowo \\ e-mail: jonisusilowibowo@unesa.ac.id \\ Program Studi Pendidikan Akuntansi, Fakultas Ekonomika dan Bisnis, Universitas Negeri Surabaya
}

\begin{abstract}
ABSTRAK : Pada pendidikan abad 21, penggunaan teknologi informasi diperlukan guna memperlancar kegiatan pembelajaran terutama dalam pengembangan materi pembelajaran. Misalnya penggunaan bahan ajar elektronik dalam bentuk e-book. Penelitian dilakukan bertujuan untuk mengembangkan dan menganalisis kelayakan pada bahan ajar e-book Akuntansi Keuangan kelas XII SMK materi aset tetap berwujud berbasis pendekatan saintifik serta respon peserta didik terhadap bahan ajar e-book. Model 4D oleh Thiagarajan, Semmel dan Semmel digunakan pada penelitian research and development (RED) ini. Tahapan yang dilakukan yakni define, design, develop, sedangkan disseminate tidak dilaksanakan. Data penelitian dianalisis dengan teknik analisis deskriptif kuantitatif. Perolehan kelayakan pada hasil penelitian ini mengungkapkan bahwa validitas materi, bahasa, dan kegrafikan terkategorikan sangat layak. Sejumlah 20 peserta didik dari kelas XII AKL SMK Rajasa Surabaya memberikan responnya terhadap bahan ajar e-book sebagai pelaksanaan uji coba terbatas yang memperoleh interpretasi sangat dipahami. Dengan demikian, bahan ajar e-book mata pelajaran Akuntansi Keuangan kelas XII SMK pada materi aset tetap berwujud berbasis pendekatan saintifik dapat digunakan pada proses pembelajaran.
\end{abstract}

Kata kunci - Aset Tetap Berwujud, E-Book, Saintifik

\begin{abstract}
In 21st century education, the use of information technology is needed to facilitate learning activities, especially in the development of learning materials. For example, the use of electronic teaching materials in the form of e-books. The research was carried out with the aim of developing and analyzing the feasibility of the financial accounting e-book teaching material for class XII SMK in the material of tangible fixed assets based on a scientific approach as well as knowing the responses of students after being given e-book teaching materials. The 4D model by Thiagarajan, Semmel and Semmel is used in this research and development $(R \mathcal{E} D)$ research. The steps taken are define, design, develop, while disseminate was not carried out. The research data were analyzed using quantitative descriptive analysis techniques. Obtaining the feasibility of the results of this study revealed that the validity of the material, language, and graphics were categorized as very feasible. A total of 20 students from class XII AKL SMK Rajasa Surabaya gave their responses to the ebook teaching material as a limited trial implementation that obtained a very well-understood interpretation. Thus, the e-book teaching materials for Financial Accounting class XII SMK on tangible fixed assets based on a scientific approach can be used in the learning process.
\end{abstract}

Keywords - Tangible Fixed Assets, E-Book, Scientific 


\section{PENDAHULUAN}

Pesatnya tingkat perkembangan ilmu pengetahuan dan teknologi (IPTEK) tentu akan membawa efek bagi kehidupan manusia, salah satunya pada bidang pendidikan. Pendidikan di era saat ini akan lebih mudah dengan memanfaatkan teknologi yang tepat guna. Pengembangan materi pembelajaran dapat membantu peserta didik untuk mempersiapkan keterampilan baru yang relevan di abad 21. Penggunaan teknologi tepat guna dapat meningkatkan kualitas dan efisensi pembelajaran guna mencetak sumber daya manusia yang unggul (Riyanto et al., 2020). Maka dari itu, manusia dituntut mampu mengintegrasikan beberapa kemampuan dari segi pengetahuan, keterampilan, sikap, dan teknologi (Saputra, 2019). Pernyataan tersebut sesuai dengan Peraturan Menteri Pendidikan dan Kebudayaan Nomor 34 Tahun 2018 pada Lampiran III mengenai Standar Proses Pembelajaran Sekolah Menengah Kejuruan (SMK)/Madrasah Aliyah Kejuruan (MAK) bahwa pada proses pembelajaran menyediakan akses untuk mengembangkan kompetensi abad 21 yang kreatif, inovatif, pola pikir kritis, penyelesaian persoalan, kerja sama, dan komunikatif dalam rangka menghadapi masa revolusi industri 4.0. Pemakaian teknologi informasi dan komunikasi pada bidang pendidikan akan memberikan kemudahan bagi peserta didik untuk memperoleh informasi di luar informasi dari guru yang tidak dibatasi oleh ruang dan waktu (Novitasari et al., 2019).

Selama proses pembelajaran berlangsung, peserta didik diharapkan dapat mengembangkan keterampilan pola pikir yang kritis dan logis dalam memecahkan masalah, keterampilan komunikasi yang baik, kreatif dan inovatif, dan kemampuan kolaborasi (Saputra, 2019). Beberapa keterampilan tersebut mengindikasikan bahwa pembelajaran telah selaras dengan kemajuan IPTEK di abad 21. Pembelajaran dikatakan efektif apabila terdapat komunikasi dua arah antara guru sebagai tenaga pendidik dan peserta didik. Pembelajaran dimaknai sebagai susunan aktivitas yang terdiri dari perencanaan, pelaksanaan, sampai penilaian (Sufairoh, 2016). Tugas guru ialah memberikan materi yang dipelajari peserta didik agar mudah dipahami. Guru juga harus mampu membuat suasana pembelajaran menjadi aktif, misalnya mampu memancing peserta didik untuk bertanya maupun menyatakan pendapat. Hal tersebut sesuai dengan kurikulum 2013 (K-13) dimana pembelajaran diarahkan untuk membentuk manusia yang berdaya guna agar semakin produktif, kreatif, dan inovatif dengan tingkat keterampilan yang signifikan (Irafahmi \& Sulastri, 2016). Landasan yang menjadi pedoman dalam pelaksanaan pendidikan yaitu kurikulum. Kualitas pendidikan yang baik dapat tercapai jika kurikulum yang dirancang selaras dengan tujuan pendidikan. Beberapa keterampilan yang dapat dikembangkan peserta didik dalam K-13, yakni mengamati, menanya, mengumpulkan informasi, mengasosiasi, dan mengomunikasi pengetahuan yang diperoleh yang disebut dengan $5 \mathrm{M}$ yang terdapat pada pembelajaran yang berbasis pendekatan saintifik.

Pemanfaatan teknologi dalam pendidikan dapat berupa pengembangan bahan ajar maupun media guna memudahkan kegiatan belajar di sekolah. Manfaat bahan ajar yang berbasis teknologi yakni untuk menghasilkan bahan ajar yang inovatif sehingga pembelajaran menjadi menarik, berkesempatan melakukan pembelajaran secara mandiri namun tetap dalam bimbingan guru, dan mempermudah penguasaan kompetensi. Perkembangan teknologi informasi dapat mendukung proses pembelajaran menjadi lebih modern yang tak terbatas pada ruang dan waktu. Pada kondisi tertentu, bahan ajar berbasis teknologi ini dapat digunakan sebagai bahan ajar alternatif, misalnya pada pembelajaran jarak jauh yang hanya dapat dilakukan secara online. Pada pembelajaran tersebut, peserta didik tetap dapat belajar secara mandiri meskipun proses pembelajaran tidak dilakukan secara tatap muka karena dibantu dengan ketersediaan bahan ajar elektronik (Wiyanto, 2017).

E-book dianggap dapat memberikan solusi sebagai sumber belajar alternatif yang mampu memberikan kenyamanan dan aksesibilitas karena ketidaktersediaan buku cetak (Enright, 2014). Penggunaan e-book berbantuan teknologi dianggap lebih fleksibel dan interaktif karena penggunaannya dilakukan secara mobile sehingga bebas dan mudah digunakan. Hal tersebut diharapkan dapat meningkatkan semangat peserta didik sehingga mampu memunculkan respon 
positif peserta didik dalam pembelajaran akuntansi (Figueiredo et al., 2016). Terlebih, jika e-book dibuat dengan mengkombinasikan pendekatan saintifik sebagai implementasi K-13 dapat mengarahkan peserta didik untuk berpikir aktif, kreatif, kritis, dan logis yang akan berdampak pada peningkatan kualitas pendidikan (Kirana \& Susilowibowo, 2020). Selain itu, e-book memiliki keunggulan dibandingkan dengan bahan ajar cetak pada umumnya karena di dalamnya dapat memuat tulisan, gambar, video, dan audio yang dapat diakses menggunakan smartphone atau komputer (Suarez and Wouudhusyen dalam Fitriani \& Rohayati, 2019).

Salah satu usaha untuk mencerdaskan kehidupan bangsa yakni melalui pendidikan yang merupakan tujuan pendidikan nasional. Hal itu selaras dengan UU RI Tahun 2003 Nomor 20 Pasal 1 Ayat (1) mengenai Sistem Pendidikan Nasional yang menyatakan bahwa penyelenggaraan pendidikan dapat melalui jalur formal maupun non-formal dan informal guna memberikan tambahan pengetahuan dan keterampilan. Pada jenjang SMK/MAK diharapkan mampu mencetak lulusan yang memiliki pengetahuan luas serta terlatih keterampilannya (Kirana \& Susilowibowo, 2020). Salah satu kompetensi keahlian di SMK Rajasa Surabaya yaitu Akuntansi Keuangan dan Lembaga (AKL). Pada kompetensi keahlian AKL di SMK Rajasa Surabaya ditemukan fenomena bahwa peserta didik belum dapat mencapai kemampuan yang optimal dalam memahami ilmu akuntansi melalui bahan ajar yang disediakan oleh sekolah. Karena hal tersebut, maka diperlukan bahan ajar dengan sentuhan inovasi pada bentuk atau model guna memberikan kemudahan pemahaman peserta didik pada materi akuntansi sehingga kemampuan peserta didik meningkat.

Berpatokan dari studi pendahuluan yang telah dipaparkan peneliti, guru masih menggunakan bahan ajar yang belum bervariasi, misalnya masih terpaku pada bahan ajar cetak dalam bentuk buku paket dan LKS. Pada buku paket belum sesuai dengan silabus, sedangkan pada LKS sudah memuat Kompetensi Dasar (KD) yang sesuai dengan silabus tetapi hanya berisi materi inti dan penyajian soal latihan yang belum berbasis Higher Order Thinking Skills (HOTS). Buku paket sebagai sumber belajar yang belum sesuai dengan silabus menyebabkan adanya perbedaan urutan materi sehingga guru harus menyesuaikan kembali jika akan menyampaikan materi kepada peserta didik. Artinya, bahan ajar cetak tersebut belum mampu mengarahkan pola pikir yang kritis dalam menyelesaikan masalah dan belum mampu memberikan kemandirian belajar pada peserta didik.

Melalui wawancara dengan guru mata pelajaran Akuntansi Keuangan di kelas XII AKL, guru berpendapat bahwa materi pada mata pelajaran tersebut membutuhkan pemahaman lebih dalam. Hal tersebut berlaku pada materi aset tetap, dimana peserta didik harus memahami materi dari pengakuan, perolehan, penilaian, penyusutan, hingga penghentian aset tetap dengan kemampuan analisis yang cermat. Ditambah saat ini pembelajaran hanya bisa dilakukan secara online menyebabkan guru kurang bisa mengontrol proses pembelajaran. Oleh karena itu, peran aktif dan kemampuan belajar mandiri harus dikuasai dengan baik oleh peserta didik disamping juga masih dalam bimbingan guru. Selain karena kesulitan dalam memahami materi, juga dikarenakan oleh penggunaan bahan ajar yang kurang efektif. Hal tersebut dirasakan oleh peneliti ketika Pengenalan Lingkungan Persekolahan (PLP) sekaligus melakukan observasi untuk studi pendahuluan. Peneliti menemukan kesulitan pemahaman konsep atas materi yang diterima peserta didik karena sistem pembelajaran online.

Guna menyelesaikan permasalahan tersebut, maka diperlukan sebuah inovasi bahan ajar alternatif dari buku cetak yang sudah menerapkan K-13 dan memuat informasi secara lengkap beserta contoh kasus terkait aset tetap agar peserta didik menjadi lebih mudah memahami konsep dari materi secara utuh. Solusi yang diberikan yakni pembuatan bahan ajar e-book yang memanfaatkan aplikasi Flip PDF Professional. E-book yang diolah dengan aplikasi tersebut dapat menampilkan buku secara online sehingga lebih fleksibel dan diharapkan dapat mengatasi permasalahan tersebut. E-book dikembangkan agar dapat menjadi bahan ajar penunjang pada proses pembelajaran online, memudahkan peserta didik memahami materi secara utuh sesuai dengan KD 
dan Indikator Pencapaian Kompetensi (IPK), dan dapat dipelajari secara mandiri. Penyusunan e-book dibuat secara sistematis yang berbasis pendekatan saintifik sesuai dengan penerapan K-13 dan berpedoman pada standar kelayakan menurut Badan Standar Nasional Pendidikan (BSNP).

Beberapa penelitian pengembangan pada bahan ajar e-book yang sudah dilakukan, antara lain penelitian oleh Saputri \& Susilowibowo (2020) yang mengembangkan produk berupa bahan ajar $e$ book mata pelajaran Praktikum Akuntansi Perusahaan Manufaktur mendapatkan rata-rata validasi sebesar $86,45 \%$ yang ditinjau dari komponen kelayakan isi, penyajian, bahasa, dan grafis yang dikategorikan sangat layak. Pratiwi \& Rochmawati (2019) mendapatkan nilai kelayakan sebesar $84,34 \%$ yang dikategorikan sangat layak dijadikan sebagai bahan ajar pada pembelajaran dan mendapatkan respon peserta didik sebesar $86,75 \%$ yang diinterpretasikan bahwa bahan ajar mampu memudahkan pemahaman peserta didik.

Berdasar latar belakang yang sudah dipaparkan, peneliti menyusun penelitian berjudul "Pengembangan Bahan Ajar E-Book Akuntansi Keuangan Kelas XII SMK pada Materi Aset Tetap Berwujud Berbasis Pendekatan Saintifik". Adapun tujuan penelitian ini, yakni (1) menganalisis proses pengembangan e-book akuntansi keuangan kelas XII SMK pada materi aset tetap berwujud berbasis pendekatan saintifik, (2) menganalisis kelayakan bahan ajar $e$-book akuntansi keuangan kelas XII SMK pada materi aset tetap berwujud berbasis pendekatan saintifik, dan (3) menganalisis respon peserta didik terhadap bahan ajar e-book akuntansi keuangan kelas XII SMK pada materi aset tetap berwujud berbasis pendekatan saintifik. Penelitian pengembangan ini akan menghasilkan sebuah bahan ajar berupa e-book dengan file dalam bentuk HTML yang dapat diakses dengan jaringan internet pada smartphone maupun komputer.

\section{TINJAUAN PUSTAKA}

\section{Pembelajaran Akuntansi}

Belajar dimaknai sebagai perubahan secara permanen yang dialami oleh peserta didik dari segi perilaku, pengetahuan, dan keterampilan berpikir yang disebabkan oleh pengalaman (Santrock, 2013). Sedangkan pembelajaran merupakan sekumpulan kegiatan yang dilakukan oleh guru dalam membimbing dan mengarahkan peserta didik sehingga memperoleh pengalaman belajar (Arifin, 2014). Pada jenjang SMK/MAK dengan program keahlian AKL, akuntansi merupakan materi yang perlu didalami dari segi teori juga praktik (Novianti \& Susilowibowo, 2015). Materi yang dikembangkan pada e-book yakni aset tetap berwujud dalam mata diklat Akuntansi Keuangan untuk kelas XII. Menurut PSAK 16 (2015), aset tetap berwujud adalah suatu aset milik perusahaan yang dioperasikan dalam kegiatan produksi baik jasa atau barang, bisa juga untuk disewakan ke pihak lain, maupun urusan administrasi lainnya yang mampu memberikan manfaat lebih dari satu tahun.

\section{Bahan Ajar Elektronik (electronic book)}

Bahan ajar diartikan sebagai pendukung dalam proses pembelajaran yang memuat segala bahan berupa informasi terkait materi pembelajaran secara utuh atas suatu konsep ilmu pengetahuan agar dapat dipelajari peserta didik (Prastowo, 2015). Perkembangan IPTEK menjadikan pembelajaran tidak hanya menggunakan buku cetak, tetapi juga buku dalam bentuk digital, salah satunya berbentuk electronic book yang disingkat e-book. E-book dianggap lebih efisien daripada bahan ajar cetak karena penyimpanan e-book dapat bertahan lama dalam bentuk file, fleksibel jika ingin menggunakannya kapanpun dan dimanapun, dan dalam pembuatan maupun memperolehnya dengan biaya yang lebih murah (Dewi dalam Fitriani \& Rohayati, 2019). E-book diolah dengan aplikasi Flip PDF Professional yang merupakan perangkat lunak yang menampilkan buku digital dengan halaman yang dapat dibolak-balik. E-book yang diolah menggunakan aplikasi tersebut dapat memuat beberapa jenis file, seperti tulisan, gambar, audio, animasi, video, link, dan sebagainya. Aplikasi Flip PDF Professional dapat mengonversi berkas dalam bentuk PDF ke HTML dan flippable di berbagai perangkat, seperti smartphone maupun komputer (Sriwahyuni et al., 2019). 


\section{Pendekatan Saintifik}

Implementasi K-13 yang perlu dititikberatkan yakni kegiatan pembelajaran yang memakai pendekatan saintifik (Susilana \& Ihsan, 2014). Sufairoh (2016) menyatakan bahwa pendekatan saintifik ialah pembelajaran yang didalamnya mengutamakan keaktifan peserta didik dalam membangun konsep, hukum, atau prinsip yang memuat lima proses berpikir. Karakteristik yang menonjol dari pendekatan saintifik ialah pusat pembelajaran berada pada peserta didik, melibatkan peserta didik pada proses kognitif untuk mengasah keterampilan berpikir tingkat tinggi, dan menumbuhkan karakter peserta didik (Wiyanto, 2017). Pendekatan saintifik tidak hanya diterapkan pada kegiatan pembelajaran, tetapi juga dimuat pada bahan ajar sehingga mampu membangkitkan dan mewujudkan pengalaman belajar yang beraneka ragam karena mengikutsertakan semua fungsi panca indera, baik fisik maupun psikis sehingga potensi yang dimiliki peserta didik berkembang dan hasil belajar menjadi maksimal (Susilana \& Ihsan, 2014).

\section{METODE}

Penelitian ini tergolong jenis R\&D guna menciptakan suatu produk yang dikembangkan dari yang sudah ada yang kemudian diuji keefektifan produk tersebut jika digunakan (Sugiyono, 2017). Penelitian ini mengembangkan produk bahan ajar berbentuk e-book mata pelajaran Akuntansi Keuangan Kelas XII SMK dengan materi aset tetap berwujud berbasis pendekatan saintifik. Model 4D pada teori Thiagarajan, Semmel dan Semmel (dalam Trianto, 2015) diterapkan pada penelitian pengembangan ini karena memiliki prosedur penelitian yang terstruktur dan tahapannya sesuai dengan karakteristik penelitian. Model 4D tersebut sebagai tahapan untuk mengembangkan sebuah produk. Tahapan yang dilalui yakni define, design, develop, dan disseminate. Dikarenakan kondisi yang tidak memungkinkan, maka penelitian ini terhenti di tahap develop.

Subjek penelitian yakni ahli materi, ahli bahasa, dan ahli grafis, serta 20 peserta didik. Angket digunakan sebagai teknik dalam pengumpulan data. Penggunaan angket terbuka yakni untuk mendapatkan data yang berisi saran dan masukan sebagai bahan untuk melakukan perbaikan pada proses telaah dari para ahli terkait bahan ajar e-book dan angket tertutup guna mendapatkan data yang berisi respon peserta didik terhadap bahan ajar e-book. Instrumen yang digunakan yakni lembar telaah dan lembar validasi yang diisikan oleh tiga ahli bidang dan angket respon yang diberikan kepada peserta didik. Pelaksanaan uji coba terbatas dilakukan pada 20 peserta didik untuk memberikan jawaban pada angket respon peserta didik. Data kualitatif dan kuantitatif digunakan pada penelitian ini. Data kualitatif didapat dari proses analisis para ahli yang berisi masukan, saran, dan komentar umum sebagai bahan perbaikan produk. Data kuantitatif didapat dari hasil validasi para ahli dan angket respon peserta didik. Berdasarkan kedua jenis data tersebut, kemudian dilakukan pengolahan data yang menghasilkan interpretasi kelayakan bahan ajar e-book dalam bentuk persentase.

Penggunaan teknik analisis deskriptif kuantitatif dilakukan di penelitian ini. Pada analisis data deskriptif didapat dari proses telaah atas kesesuaian bahan ajar e-book berdasarkan kelayakan isi, penyajian, bahasa, dan kegrafikan yang kemudian dikonversi dalam bentuk persentase untuk menentukan kriteria kelayakan terhadap bahan ajar e-book Akuntansi Keuangan Kelas XII SMK pada materi aset tetap berwujud yang didasarkan pada kriteria interpretasi data menurut Riduwan (2016). Sedangkan analisis data kuantitatif didapat dari hasil validasi masing-masing ahli bidang berdasarkan pada lembar validasi yang selanjutnya dilakukan perhitungan skor penilaian dengan menggunakan skala Likert dengan range 1-5 dan data dari angket respon yang dibagikan kepada peserta didik disajikan dengan skala Guttman dengan dua pilihan jawaban tegas "ya-tidak". Hasil interpretasi oleh para ahli menunjukkan tingkat kelayakan dari bahan ajar e-book sehingga dapat dimanfaatkan untuk pembelajaran. Bahan ajar e-book dapat dikatakan layak jika mendapatkan nilai persentase $>60 \%$ agar dapat dipakai menjadi bahan ajar pendukung pada proses pembelajaran. 


\section{PEMBAHASAN}

Proses Pengembangan Bahan Ajar E-book Akuntansi Keuangan Kelas XII SMK pada Materi Aset Tetap Berwujud Berbasis Pendekatan Saintifik

Bahan ajar e-book dikembangkan mengacu pada model 4D menurut Thiagarajan yang dimulai dari tahap define hingga dessiminate. Namun penelitian terbatas pada tahap develop sehingga tahap dessiminate tidak dijalankan. Tahapan-tahapan tersebut dilakukan agar bahan ajar e-book yang dibuat layak dipergunakan pada proses pembelajaran. Tahapan yang dilakukan dalam mengembangkan bahan ajar e-book Akuntansi Keuangan Kelas XII dimulai dari pendefinisian. Analisis yang harus dilakukan pada tahapan ini yakni meliputi analisis ujung depan, karakteristik peserta didik, tugas, konsep, dan merumuskan tujuan.

Langkah pertama ialah analisis ujung depan untuk mengidentifikasi permasalahan selama proses pembelajaran di sekolah. Ditemukan fakta bahwa di SMK Rajasa Surabaya pembelajarannya sudah menggunakan K-13 edisi revisi, tetapi penggunaan bahan ajar masih berupa buku cetak yang difasilitasi oleh sekolah. Perlunya penggunaan bahan ajar non-cetak berupa e-book pada sistem pembelajaran online dianggap mampu menyediakan kemudahan akses informasi terhadap materi. Materi aset tetap berwujud dirasa cocok dibuatkan bahan ajar e-book yang berbasis pendekatan saintifik yang mampu mengasah kemampuan peserta didik karena materi tersebut membutuhkan tingkat pemahaman yang mendalam dan keterampilan analisis yang cermat karena materi yang saling terkait satu sama lain. Materi pada e-book disediakan lengkap beserta contoh soal dan pengoperasiannya melalui smartphone atau komputer sehingga kemandirian belajar peserta didik akan terbentuk. Sesuai dengan pernyataan Abdullah (2012), bahwa sumber belajar yang digunakan sebagai bahan ajar harus disesuaikan dengan tujuan pembelajaran, mempertimbangkan keekonomisan, praktis, sederhana, dan mudah diperoleh. Langkah kedua ialah menganalisis karakteristik peserta didik. Fakta yang didapatkan yaitu peserta didik belum berperan aktif karena KD pada buku yang digunakan belum sesuai dengan silabus. Langkah ketiga ialah analisis tugas guna menentukan jenis tugas yang harus diberikan kepada peserta didik dengan materi aset tetap berwujud berbasis pendekatan saintifik yang sesuai dengan IPK pada KD. Tugas dirumuskan menggunakan soal bertipe HOTS. Langkah keempat ialah analisis konsep dilakukan guna pembuatan peta konsep yang berisi materi sesuai dengan KD dan IPK agar dapat dipahami secara sistematis oleh peserta didik. Langkah kelima ialah merumuskan tujuan pembelajaran dengan cara menganalisis KD dan IPK yang digunakan. Materi yang dimuat terdiri dari 3 KD, yaitu 3.13, 3.14, $3.15,4.13$, 4.14, dan 4.15 terkait materi aset tetap berwujud, mulai dari pengakuan, perolehan, penilaian, penyusutan, dan pengembangan serta penghentian aset tetap.

Tahapan kedua yaitu penyusunan desain $e$-book yang berpedoman pada standar ketetapan oleh BSNP (2014) yang kemudian disesuaikan oleh peneliti dengan e-book yang dikembangkan. Perancangan format awal e-book yaitu menyusun struktur e-book yang terdiri dari bagian pembuka, inti, dan penutup yang berpedoman pada struktur buku menurut Prastowo (2015). Rancangan e-book dibuat berdasarkan pendekatan saintifik pada K-13 yang memuat lima tahap berpikir.

Selanjutnya, dilakukan penyusunan desain awal $e$-book berisi konsep dari materi $e$-book yang menggunakan pendekatan saintifik yang mencakup $5 \mathrm{M}$, pemilihan tema $e$-book, penyusunan gambar ilustrasi, dan pengaturan layout. Pada bagian pembuka, terdapat sampul depan e-book yang disertai dengan judul dan ilustrasi yang menggambarkan isi dari e-book dengan materi aset tetap berwujud. Petunjuk penggunaan e-book dicantumkan agar peserta didik mengetahui fitur dan ikon-ikon yang ada di dalam e-book. Daftar isi berisi tiga bab yang membahas tentang aset tetap berwujud yang disertai rincian sub bab dan nomor halaman agar peserta didik mudah menemukan materi yang ingin dituju. Disematkan fitur growth character berupa kalimat motivasi disertai ilustrasi tokoh sebelum pembahasan materi guna membangkitkan semangat belajar peserta didik. Sampul bab 
memuat judul bab, ilustrasi sesuai dengan materi bab yang dibahas, apersepsi, KD dan IPK yang disusun dalam bentuk tabel, serta kata kunci. Terdapat juga peta konsep yang berisi konsep dari materi-materi inti yang dibahas pada e-book. Bagian inti memuat uraian materi aset tetap berwujud secara rinci tentang pengenalan aset tetap, penyusutan aset tetap, dan pengembangan serta penghentian aset tetap. Pada setiap bab, materi disusun berbasis pendekatan saintifik dengan langkah pembelajaran 5M. Pada bagian "Ayo Mengamati" disajikan video pembelajaran terkait materi di bab tersebut yang dapat diklik langsung agar dapat memutar video. "Ayo Menanya" berisi pertanyaan yang diajukan oleh peserta didik kepada guru terkait video pembelajaran yang telah diamati sebelumnya. "Ayo Mengumpulkan Informasi" memuat informasi detail terkait materi aset tetap berwujud lengkap dengan contoh soal yang kongkrit. "Ayo Mengasosiasi" berisi soal berupa studi kasus yang harus didiskusikan dengan teman kelompok untuk melatih kerja sama dan rasa tanggung jawab dalam menyelesaikan masalah, selain itu terdapat fitur Refleksi Diri guna menilai diri sendiri setelah mempelajari dan mengerjakan soal studi kasus. "Ayo Mengomunikasi" berisi instruksi kepada peserta didik untuk menyampaikan hasil diskusinya kepada kelompok lain agar terjadi pertukaran informasi dan pendapat. Bagian akhir dari inti e-book yakni Soal Evaluasi yang berisi kumpulan soal pilihan ganda dan uraian sesuai dengan materi bab yang telah dipelajari yang harus dikerjakan secara individu untuk mengukur tingkat pemahaman peserta didik. Semua soal dibuat dengan tingkat berpikir analisis, evaluasi, dan mencipta dengan tipe soal HOTS. Bagian penutup, menampilkan glosarium yang merupakan kumpulan dari istilah yang sulit dimengerti, kunci jawaban guna mencocokkan jawaban dari peserta didik, daftar pustaka yang mutakhir sebagai sumber referensi penyusunan materi $e$-book, dan profil dari peneliti. Dari tahap-tahap yang telah disebutkan tersebut, maka menghasilkan draft I e-book.

Tahapan ketiga yaitu pengembangan produk sebagai hasil dari draft I e-book. Berdasarkan draft I tersebut, maka dilakukan telaah materi oleh dosen Program Studi Pendidikan Akuntansi FEB UNESA juga oleh guru yang mengajar pelajaran Akuntansi Keuangan SMK Rajasa Surabaya, ahli bahasa oleh dosen Jurusan Bahasa dan Sastra Indonesia FBS UNESA, dan ahli grafis oleh dosen Jurusan Teknologi Pendidikan FIP UNESA. Saran dan masukan dari para ahli kemudian dicantumkan pada lembar telaah.

Berdasarkan telaah dari dua ahli materi, diperoleh hasil bahwa materi sudah disajikan dengan runtut dan mendalam sesuai dengan KD dan IPK yang disertai dengan contoh soal yang konkrit. Masukan yang diberikan yaitu pemilihan kata kerja operasional pada IPK harus dimulai dari tingkat analisis, evaluasi, dan mencipta, penyusunan keseluruhan soal harus berbasis HOTS, penggunaan istilah akuntansi terkait aset tetap harus taat dan teratur berdasarkan pada Pernyataan Standar Akuntansi Keuangan (PSAK), dan penambahan kalimat komunikatif sehingga seolah-olah peserta didik berkomunikasi dengan penulis. Adanya penambahan fitur $Q R$ Code pada bagian "Ayo Mengamati" yang diletakkan di bawah video jika ingin memindai alamat URL pada perangkat lain. Dilakukan perubahan intsruksi pada bagian "Ayo Menanya" yakni peserta didik mengajukan pertanyaan kepada guru dengan dibuatkan kolom pertanyaan.

Berdasarkan telaah ahli bahasa diperoleh hasil bahwa bahasa yang dipakai telah sepadan dengan jenjang perkembangan peserta didik, mampu memotivasi, dan membentuk pola pikir yang kritis, serta kebakuan istilah berdasarkan Kamus Besar Bahasa Indonesia (KBBI), penulisan istilah dan simbol/lambang sudah tepat. Beberapa hal yang perlu diperbaiki dari segi bahasa yaitu penyusunan struktur kalimat yang kurang tepat, seperti pemborosan kata dan penggunaan kalimat yang terlalu panjang sehingga kurang efektif ketika dibaca, pemakaian huruf, kata, dan tanda baca perlu disesuikan dengan PUEBI. Perlu diperhatikan kekonsistenan penggunaan kata sapaan, penambahan kalimat penguat motivasi setelah pengerjaan soal latihan, dan mencantumkan tambahan referensi pada isi $e$-book. 
Kemudian, berdasarkan telaah dari ahli grafis diperoleh hasil bahwa secara keseluruhan bahan ajar e-book sudah didesain dengan baik dan sesuai dengan perkembangan IPTEK. Bahan ajar $e-$ book sesuai dengan standar ISO, penyusunan layout yang memperhatikan unsur tipografi dan ilustrasi yang harmonis pada cover dan isi memberikan tampilan yang bagus untuk dipandang. Pemilihan tema, warna, jenis, dan ukuran huruf berdasarkan fungsi materi yang disajikan sehingga peserta didik nyaman untuk membaca bahan ajar e-book. Sedikit hal yang perlu direvisi yakni penggunaan gradasi warna yang lebih dipertebal di judul bab agar tulisan judul terlihat jelas.

Setelah didapatkannya saran dan masukan dari para ahli, berikutnya dilakukan perbaikan pada bahan ajar e-book yang kemudian menghasilkan draft II e-book. Hasil dari draft II e-book tersebut kemudian para ahli dapat memberikan penilaian kelayakan bahan ajar $e$-book dengan memberikan skor nilai 1 sampai 5 di lembar validasi. Berdasarkan data tersebut, dilakukan analisis dan hasilnya diinterpretasikan dalam bentuk persentase. Hasil persentase validasi dari para ahli menjadi pedoman agar bahan ajar e-book siap diperuntukkan pada peserta didik untuk pelaksanaan uji coba terbatas. Peserta didik yang berjumlah 20 dari kelas XII AKL SMK Rajasa Surabaya menjadi subjek uji coba terbatas. Dikarenakan pembelajaran saat ini belum bisa dilakukan tatap muka, maka uji coba tersebut dilakukan secara online dengan membagikan link e-book untuk dipelajari oleh peserta didik. Selanjutnya, perolehan respon peserta didik atas bahan ajar e-book tersebut didapatkan dengan pengisian angket berupa google form. Hasil dari uji coba respon peserta didik kemudian dianalisis dan diinterpretasikan dalam bentuk persentase untuk mengukur keterpahaman peserta didik.

\section{Kelayakan Bahan Ajar E-book Akuntansi Keuangan Kelas XII SMK pada Materi Aset Tetap Berwujud Berbasis Pendekatan Saintifik}

Penilaian kelayakan bahan ajar e-book berbasis pendekatan saintifik didapat dari hasil validasi para ahli. Penilaian bahan ajar e-book dilakukan menggunakan kuisioner tertutup untuk menghasilkan nilai kelayakan melalui perhitungan skor dari lembar validasi yang diolah dengan metode persentase. Perolehan hasil persentase tersebut kemudian diinterpretasikan berdasarkan kriteria kelayakan menurut Riduwan (2016).

Dosen Program Studi Pendidikan Akuntansi FEB UNESA yaitu Drs. Joni Susilowibowo, M.Pd. dan guru pengampu mata pelajaran Akuntansi Keuangan SMK Rajasa Surabaya yaitu Heni Supartini, S.Pd. selaku ahli materi yang melakukan proses telaah dan validasi pada bahan ajar e-book Akuntansi Keuangan Kelas XII SMK berbasis pendekatan saintifik. Berikut hasil rekapitulasi skor validasi materi.

Tabel 1. Hasil Validasi Kelayakan dari Segi Materi

\begin{tabular}{|c|l|c|c|c|}
\hline No & \multicolumn{1}{|c|}{ Komponen } & Ahli 1 & Ahli 2 & $\begin{array}{c}\text { Rata-rata } \\
\text { Persentase }\end{array}$ \\
\hline 1 & Cakupan materi & $86,67 \%$ & $80 \%$ & $83,33 \%$ \\
\hline 2 & Akurasi materi & $86,67 \%$ & $100 \%$ & $93,33 \%$ \\
\hline 3 & Kemutakhiran dan kontekstual & $86,67 \%$ & $100 \%$ & $93,33 \%$ \\
\hline 4 & $\begin{array}{l}\text { Ketaatan pada hukum dan } \\
\text { perundang-undangan }\end{array}$ & $95 \%$ & $80 \%$ & $87,50 \%$ \\
\hline 5 & Teknik Penyajian & $85 \%$ & $100 \%$ & $92,50 \%$ \\
\hline 6 & Pendukung, penyajian materi & $90 \%$ & $95 \%$ & $92,50 \%$ \\
\hline 7 & Penyajian pembelajaran & $80 \%$ & $80 \%$ & $80 \%$ \\
\hline 8 & Kelengkapan penyajian & $95 \%$ & $100 \%$ & $97,50 \%$ \\
\hline Rerata Kelayakan Materi & $\mathbf{8 8 , 1 2 \%} \%$ & $\mathbf{9 1 , 8 7 \%}$ & $\mathbf{8 9 , 9 9 \%}$ \\
\hline Kategori & \multicolumn{3}{|c|}{ Sangat Layak } \\
\hline
\end{tabular}

Sumber: Diolah oleh Peneliti (2021) 
Dari data tersebut, kelayakan bahan ajar e-book yang ditinjau dari segi materi memperoleh persentase sebesar $89,99 \%$ yang dikategorikan sangat layak. Perolehan persentase tersebut didapat dari hasil rata-rata dua ahli materi. Persentase kelayakan materi tersebut didapatkan karena setelah dilakukannya perbaikan yang mengacu dari saran dan masukan ahli. Bahan ajar e-book dibuat sudah berdasarkan aspek kelayakan isi dan kelayakan penyajian. Bahan ajar e-book sudah mencantumkan KD dan IPK yang sesuai dengan silabus mata pelajaran Akuntansi Keuangan kelas XII pada K-13, keakurasian materi aset tetap yang sikron dengan PSAK 16, cakupan materi disajikan cukup baik secara mendalam beserta contoh soal yang konkrit, dan latihan soal berbasis HOTS dengan variasi soal pilihan ganda dan uraian untuk melatih tingkat berpikir peserta didik. Penambahan fitur growth character pada awal bab mampu membangkitkan motivasi peserta didik untuk memiliki tahapan berpikir yang mendasari proses belajar dengan $5 \mathrm{M}$ dan bahan ajar $e$-book yang sudah lengkap mulai dari pendahuluan, isi, glosarium, dan menggunakan referensi yang mutakhir. Perolehan persentase validasi materi $>80 \%$, maka bahan ajar e-book yang dibuat telah mengacu pada standar yang ditetapkan oleh BSNP (2014). Perolehan skor dari beberapa komponen yang menjadi acuan validasi dari segi materi, seperti cakupan materi yang dimuat cukup lengkap dengan tujuan pembelajaran, ketaatan pada hukum dan Perundang-Undangan yang dilihat dari aspek keterampilan kurang menunjukkan tingkat pengetahuan C3 ke atas, penyajian pembelajaran menjadikan peserta didik cukup interaktif dan partisipatif dalam mencapai tujuan pembelajaran dan cukup baik merangsang kedalaman berpikir peserta didik. Hasil kelayakan materi dari bahan ajar e-book tersebut sejalan dengan penelitian oleh Kirana \& Susilowibowo (2020) yang memperoleh hasil rerata sebesar 85,9\% yang berkategori sangat layak dengan rincian dari aspek kelayakan isi sebesar 86,9\% dan kelayakan penyajian sebesar $85 \%$. Penelitian lain yang dilakukan oleh Fitriyani \& Susanti (2020) mendapatkan hasil kelayakan materi bahan ajar e-book interaktif sebesar 79,9\% yang termasuk dalam kriteria layak karena tampilan bahan ajar yang baik tetapi masih ada yang perlu dibenahi kembali, namun sudah dapat dikatakan layak untuk dilakukan uji coba. Ditemukan juga hasil pada penelitian lain oleh Kholifah et al. (2017) pada pengembangan e-book mata kuliah Akuntansi Keuangan dengan nilai $89,2 \%$ yang terkategorikan sangat layak berdasarkan aspek umum, substansi materi, dan desain pembelajaran sehingga $e$-book siap digunakan pada pembelajaran.

Dosen Jurusan Bahasa dan Sastra Indonesia FBS UNESA yaitu Prima Vidya Asteria, S.Pd., M.Pd. sebagai validator yang memberikan penilaian kelayakan dari segi bahasa. Berikut penyajian tabel hasil validasi kelayakan bahasa.

Tabel 2. Hasil Validasi Kelayakan dari Segi Bahasa

\begin{tabular}{|c|l|c|}
\hline No & \multicolumn{1}{|c|}{ Komponen } & Persentase \\
\hline 1 & Kesesuaian dengan tingkat perkembangan peserta didik & $80 \%$ \\
\hline 2 & Keterbacaan & $100 \%$ \\
\hline 3 & Kemampuan memotivasi & $90 \%$ \\
\hline 4 & Kelugasan & $90 \%$ \\
\hline 5 & Koherensi dan keruntutan alur berpikir & $100 \%$ \\
\hline 6 & Kesesuaian dengan kaidah bahasa Indonesia & $90 \%$ \\
\hline 7 & Teknik penyajian & $100 \%$ \\
\hline \multicolumn{2}{|l|}{ Rerata Kelayakan Bahasa } & $\mathbf{9 2 , 8 5 \%}$ \\
\hline \multicolumn{2}{|l|}{ Kategori } & Sangat Layak \\
\hline
\end{tabular}

Sumber: Diolah oleh Peneliti (2021)

Bersumber pada data tersebut, hasil validasi kelayakan bahasa memperoleh persentase sebesar $92,85 \%$ yang tergolong dalam kriteria sangat layak. Hasil validasi kelayakan tersebut didapatkan setelah dilakukan perbaikan berdasarkan telaah dari ahli bahasa. Kelayakan dari segi bahasa pada bahan ajar e-book sudah memuat beberapa aspek yang menganut pada aturan dari BSNP 
(2014), yaitu cukup sepadan dengan jenjang perkembangan peserta didik, memberikan keterpahaman atas bacaan, mampu memberikan motivasi pada peserta didik untuk mempelajari materi, mendorong peserta didik untuk memiliki pola pikir yang kritis, keruntutan alur berpikir, kekonsistenan dalam penyajian istilah dan simbol, dan penulisan istilah asing. Perolehan skor dari salah satu komponen yang menjadi acuan validasi dari segi bahasa yakni ketepatan dengan tingkat perkembangan peserta didik yang bermakna bahwa pemakaian bahasa kurang mampu menggambarkan contoh secara abstrak dan bahasa yang kurang tepat dengan tingkat emosional peserta didik sehingga kurang mampu memberikan gambaran atas suatu konsep. Kelayakan tersebut sesuai dengan hasil penelitian oleh Saputri \& Susilowibowo (2020) yang mendapatkan kriteria layak dengan persentase sebesar $78,57 \%$. Persentase tersebut membuktikan bahwa penggunaan bahasa yang sangat mudah dipahami dan mampu mendorong motivasi peserta didik. Selain itu, Fitriani \& Rohayati (2019) juga memperoleh kelayakan bahasa pada bahan ajar e-book berbasis android sebesar $90 \%$ dengan interpretasi sangat layak. Hal tersebut karena aspek-aspek yang menjadi indikator kelayakan bahasa pada bahan ajar e-book sudah disusun dengan baik.

Hasil kelayakan dari segi grafis diperoleh dari telaah dan validasi yang dilakukan oleh dosen Jurusan Teknologi Pendidikan FIP UNESA yaitu Dr. Utari Dewi, S.Sn., M.Pd. dengan rincian hasil validasi kelayakan grafis sebagai berikut.

Tabel 3. Hasil Validasi Kelayakan dari Segi Grafis

\begin{tabular}{|c|l|c|}
\hline No & \multicolumn{1}{|c|}{ Komponen } & Persentase \\
\hline 1 & Ukuran bahan ajar & $100 \%$ \\
\hline 2 & Tata letak cover bahan ajar & $85,71 \%$ \\
\hline 3 & Tipografi cover bahan ajar & $90 \%$ \\
\hline 4 & Ilustrasi cover bahan ajar & $93,33 \%$ \\
\hline 5 & Tata letak isi bahan ajar & $91,67 \%$ \\
\hline 6 & Tipografi isi bahan ajar & $92,72 \%$ \\
\hline 7 & Ilustrasi bahan ajar & $96,67 \%$ \\
\hline \multicolumn{2}{|l|}{ Rerata Kelayakan Grafis } & $\mathbf{9 2 , 8 7 \%}$ \\
\hline Kategori & Sangat Layak \\
\hline
\end{tabular}

Sumber: Diolah oleh Peneliti (2021)

Berdasarkan pada tabel hasil validasi dari segi grafis, diperoleh kriteria kelayakan yang sangat layak dengan persentase sebesar $92,87 \%$. Hal tersebut dikarenakan bahan ajar e-book yang dibuat secara keseluruhan sudah disajikan dengan ukuran yang sesuai standar, cukup baik pada penataan desain cover yang meliputi pemilihan ukuran dan jenis huruf yang proporsional, warna yang kontras, dan penggunaan ilustrasi yang menggambarkan isi materi. Pada bagian isi, penyusunan tata letak sesuai pola sudah konsisten, baik dilihat dari pengaturan margin, paragraf, spasi, gambar, dan angka untuk halaman. Peranan IPTEK yang dimanfaatkan pada produk ini agar memudahkan peserta didik untuk mengoperasikannya. Bahan ajar e-book dibuat agar dapat diakses melalui smartphone dan komputer sehingga lebih fleksibel. Perolehan skor dari salah satu komponen yang menjadi acuan validasi dari segi grafis yakni tipografi pada cover bahan ajar e-book memiliki tata letak dari judul, pengarang, dan logo yang sudah baik, namun pada penggunaan ilustrasi dengan resolusi kurang baik sehingga gambar terlihat kurang jernih. Hasil validasi tersebut selaras dengan penelitian yang dilakukan oleh Pratiwi \& Rochmawati (2019) bahwa bahan ajar e-book interaktif yang dikembangkan memperoleh skor kelayakan sebesar $84,34 \%$ yang diinterpretasikan sangat layak. Selanjutnya, penelitian oleh Laili \& Rohayati (2018) yang memperoleh kelayakan grafis sebesar 83\% yang diinterpretasikan bahwa pengembangan bahan ajar e-book sangat layak untuk dipakai sebagai bahan ajar karena disusun sesuai dengan aspek kelayakan kegrafikan menurut strandar oleh BSNP (2014) yang meliputi indikator desain pada cover dan isi. Berikutnya Novianti \& Susilowibowo (2015) 
melakukan pengembangan berupa modul akuntansi dengan materi aset tetap yang mendapatkan persentase $82 \%$ yang di dalamnya memuat komponen kelayakan menurut kegrafikan dan desain buku.

Riduwan (2016) menyatakan bahwa untuk menentukan layak atau tidaknya suatu bahan ajar ditentukan oleh perolehan persentase validasi dari ahli. Rekapitulasi hasil persentase dari segi materi sebesar $89,99 \%$, bahasa sebesar $92,85 \%$, dan grafis sebesar 92,87\%. Kemudian nilai persentase tersebut dirata-rata sehingga menghasilkan persentase sebesar 91,90\%. Karena perolehan nilai persentase $>80 \%$, maka bahan ajar tersebut dinyatakan sangat layak untuk difungsikan sebagai bahan ajar pendukung pada proses pembelajaran.

\section{Respon Peserta Didik Terhadap Bahan Ajar E-book Akuntansi Keuangan Kelas XII SMK pada Materi Aset Tetap Berwujud Berbasis Pendekatan Saintifik}

Untuk mengetahui tanggapan peserta didik terhadap bahan ajar e-book, maka dilakukan uji coba. Pelaksanaan uji coba produk tersebut terbatas hanya kepada 20 peserta didik dari kelas XII AKL SMK Rajasa Surabaya. 20 responden tersebut telah menempuh mata pelajaran Akuntansi Keuangan Kelas XII semester 1 pada KD 3.13, 3.14, 3.15, 4.13, 4.14, dan 4.15. Penentuan responden dilakukan secara random sejumlah 20 sebagai sampel agar dapat menggambarkan populasi. Peneliti melakukan uji coba terbatas secara online dikarenakan belum dilaksanakannya pembelajaran tatap muka di sekolah tersebut. Tahap uji coba dilakukan dengan membagikan link e-book untuk dipelajari oleh peserta didik. Kemudian, angket respon peserta didik disajikan dalam bentuk google form agar dapat diisi oleh peserta didik. Angket tersebut terdiri dari 15 pertanyaan yang dapat dijawab dengan memilih jawaban "ya" atau "tidak". Jika didapatkan pilihan "ya", maka memiliki skor 1 dan jika didapatkan pilihan "tidak", maka memiliki skor 0. Dalam lembar angket respon peserta didik memuat beberapa komponen, antara lain isi, penyajian, kebahasaan, dan kegrafikan.

Tabel 4. Hasil Analisis Respon Peserta Didik

\begin{tabular}{|c|l|c|}
\hline No & \multicolumn{1}{|c|}{ Komponen } & Persentase \\
\hline 1 & Isi & $100 \%$ \\
\hline 2 & Penyajian & $95 \%$ \\
\hline 3 & Bahasa & $95 \%$ \\
\hline 4 & Kegrafikan & $94,17 \%$ \\
\hline Rerata Respon Peserta Didik & $\mathbf{9 6 , 0 4 \%}$ \\
\hline Kategori & Sangat Dipahami \\
\hline
\end{tabular}

Sumber: Diolah oleh Peneliti (2021)

Perolehan persentase respon peserta didik terhadap e-book yang dikembangkan mendapatkan nilai rerata sebesar 96,04\% yang berkategori sangat dipahami. Berdasarkan perolehan respon tersebut, membuktikan bahwa bahan ajar e-book menyajikan bacaan yang sangat mudah dipahami oleh peserta didik. Hal tersebut sejalan dengan teori menurut Riduwan (2016) yang menyatakan bahwa jika memperoleh skor $>80 \%$, maka pengembangan bahan ajar tersebut dapat diiterpretasikan dalam kategori sangat dipahami. Selaras dengan hasil tersebut, terdapat penelitian yang dilakukan oleh Sriwahyuni et al. (2019) yang memperoleh skor rerata sebesar 92,67\% yang memuat aspek penyajian, materi, dan kebermanfaatan. Penelitian lain oleh Pratiwi \& Rochmawati (2019) mendapatkan presentase respon peserta didik sebesar $86,75 \%$ yang artinya bahwa e-book yang dikembangkan mampu memberikan kemudahan peserta didik dalam memahami materi sesuai dengan tingkat usia dan pengetahuannya. Oktaviana \& Susilowibowo (2017) juga melakukan penelitian serupa yakni pengembangan bahan ajar yang memperoleh rerata respon peserta didik dengan skor sebesar $93,66 \%$ yang diinterpretasikan bahwa bahan ajar dapat memberikan pemahaman materi pada peserta didik yang ditinjau dari aspek kualitas isi, tujuan, instruksional, dan 
teknis. Berdasarkan pemaparan tersebut, maka disimpulkan bahwa bahan ajar elektronik berupa $e$ book mampu memberikan kemudahan pemahaman materi oleh peserta didik pada proses pembelajaran dan dapat dijadikan sebagai bahan ajar alternatif selain bahan ajar cetak.

\section{KESIMPULAN}

Berlandaskan pada hasil penelitian dan pembahasan yang sudah disebutkan, kesimpulan yang didapatkan bahwa pada proses pengembangan bahan ajar e-book Akuntansi Keuangan kelas XII SMK pada materi aset tetap berwujud berbasis pendekatan saintifik berpedoman pada model 4D menurut Thiagarajan. Prosedur 4D tersebut yakni define, design, develop, dan disseminate. Melainkan untuk tahap disseminate tidak dapat dilaksanakan karena adanya kondisi yang tidak mendukung.

Penilaian kelayakan atas bahan ajar e-book Akuntansi Keuangan kelas XII SMK pada materi aset tetap berwujud berbasis pendekatan saintifik memperoleh interpretasi yakni sangat layak yang didapat dari hasil validasi materi, bahasa, dan grafis. Penentuan kelayakan ditinjau dari komponen kelayakan isi, penyajian, bahasa, dan grafis. Hal tersebut dikarenakan oleh penyusunan bahan ajar yang menerapkan ketentuan yang bersumber pada BSNP (2014) dan penginterpretasian skor kelayakan menurut Riduwan (2016).

Hasil analisis respon dari 20 peserta didik terhadap bahan ajar e-book Akuntansi Keuangan kelas XII SMK pada materi aset tetap berwujud berbasis pendekatan saintifik yang didapat dari pelaksanaan uji coba terbatas membuktikan bahwa peserta didik sangat memahami bahan ajar e-book yang mengacu pada komponen isi, penyajian, bahasa, dan grafis. Berdasarkan hasil tersebut, maka bahan ajar e-book dapat dijadikan sebagai bahan ajar penunjang pada proses pembelajaran.

\section{DAFTAR PUSTAKa}

Abdullah, R. (2012). Pembelajaran berbasis pemanfaatan sumber belajar. Jurnal Ilmiah DIDAKTIKA, XII(2), 216-231.

Arifin, Z. (2014). Konsep dan Model Pengembangan Kurikulum. PT Remaja Rosdakarya.

BNSP. (2014a). Naskah Akademik Instrumen Penilaian Buku Teks Kelayakan Kegrafikan. BSNP.

BNSP. (2014b). Naskah Akademik Instrumen Penilaian Buku Teks Kelompok Peminatan Ekonomi. BSNP.

Enright, S. (2014). Ebooks: The Learning and Teaching Perspective. Ebooks in Education: Realising the Vision, 21-33. https://doi.org/10.5334/bal.d

Figueiredo, M., Bidarra, J., \& Bostad, R. (2016). The Development Of an E-Book for Teaching and Learning Mathematics. Lecture Notes in Computer Science (including Subseries Lecture Notes in Artificial Intelligence and Lecture Notes in Bioinformatics), III, 49-56. https://doi.org/10.1007/978-3319-40238-3_5

Fitriani, I., \& Rohayati, S. (2019). Pengembangan E-Book Berbasis Android Dengan Pendekatan Saintifik Pada Mata Pelajaran Administasi Pajak Kelas XII Akuntansi Di SMK Negeri 2 Buduran. Jurnal Pendidikan Akuntansi, 7(1), 11-20.

Fitriyani, A. V., \& Susanti. (2020). Bahan Ajar E-Book Interaktif Mata Pelajaran Praktikum Akuntansi Lembaga Berbasis Kontekstual. Jurnal Penelitian Dan Pengembangan Pendidikan, 4(3), 514-525. https://ejournal.undiksha.ac.id/index.php/JJL/article/view/29740

IAI. (2015). Pernyataan Standar Akuntansi Keuangan (PSAK) No. 16 Tentang Aset Tetap Edisi Revisi 2011. Dewan Standar Akuntansi Keuangan Ikatan Akuntan Indonesia.

Irafahmi, D. T., \& Sulastri. (2016). Developing an Accounting Textbook Using Collaborative Learning and IFRS for Senior High School Students in Indonesia. Asian Journal of Accounting Research, 1(2), 52-61. https://doi.org/10.1108/ajar-2016-01-02-b003

Kemendikbud. (2003). Undang-Undang RI Nomor 20 Tahun 2003 tentang Sistem Pendidikan Nasional (pp. 1-38). simkeu.kemdikbud.go.id

Kemendikbud. (2018). Salinan Lampiran III Peraturan Menteri Pendidikan dan Kebudayaan Nomor 34 
Tahun 2018 tentang Standar Proses Pembelajaran Sekolah Menengah Kejuruan (SMK)/Madrasah Aliyah Kejuruan (MAK). jdih.kemdikbud.go.id

Kholifah, S., Hartanto, P., \& Koerniawan, I. (2017). Pengembangan E-Book dengan Software Flipbookmaker untuk Pembelajaran Mata Kuliah Akuntansi Keuangan di STEKOM Semarang. Equilibria Pendidilan Jurnal Ilmiah Pendidikan Ekonomi, 2(2), 69-78. http://journal.upgris.ac.id/index.php/equilibriapendidikan

Kirana, R. W. C., \& Susilowibowo, J. (2020). Pengembangan Bahan Ajar E-Book Praktikum Akuntansi Perusahaan Dagang Berbasis Scientific Approach Sebagai Sumber Belajar Alternatif. Jurnal Pendidikan Akuntansi Indonesia, 18(1), 80-90.

Laili, Y. N., \& Rohayati, S. (2018). Pengembangan Bahan Ajar Elektronik Berbasis Android Dengan Pendekatan Saintifik pada Mata Pelajaran Perbankan Dasar di SMK Negeri 2 Kediri. Jurnal Pendidikan Akuntansi, 6(3), 255-262.

Novianti, D. A., \& Susilowibowo, J. (2015). Pengembangan Modul Akuntansi Aset Tetap Berbasis Pendekatan Saintifik sebagai Pendukung Implementasi K-13 di SMKN 2 Buduran. Jurnal Pendidikan Akuntansi, 3(1), 1-13.

Novitasari, D., Ratnawuri, T., \& Pritandhari, M. (2019). Pengembangan Media Pembelajaran Electronic Book (E-Book) Berbasis Edmodo Kelas X SMK Kartikatama Metro. Jurnal Pendidikan Ekonomi UM Metro, 7(2), 107-115. https://doi.org/10.2207/jjws.88.427

Oktaviana, P., \& Susilowibowo, J. (2017). Pengembangan Handout Berbasis Android Sebagai Pendukung Bahan Ajar untuk Mata Pelajaran Akuntansi Materi Akuntansi Persediaan di Kelas XI Akuntansi SMK Negeri 2 Tuban. Jurnal Pendidikan Akuntansi, 5(3), 1-9.

Prastowo, A. (2015). Panduan Kreatif Membuat Bahan Ajar Inovatif. DIVA Press.

Pratiwi, A. Z., \& Rochmawati. (2019). Pengembangan Bahan Ajar E-Book Interaktif Pendekatan Kurikulum 2013 Mata Pelajaran Praktikum Akuntansi Lembaga/Instansi Pemerintah Kelas XI AKL SMK Negeri 1 Lamongan. Jurnal Pendidikan Akuntansi, 07(02), 145-151.

Riduwan. (2016). Skala Pengukuran Variabel-variabel Penelitian. Alfabeta.

Riyanto, Amin, M., Suwono, H., \& Lestari, U. (2020). The New Face of Digital Books in Genetic Learning: A Preliminary Development Study for Students' Critical Thinking. International Journal of Emerging Technologies in Learning, 15(10), 175-190. https://doi.org/10.3991/ijet.v15i10.14321

Santrock, J. W. (2013). Psikilogi Pendidikan (Jilid 1E2). Salemba Humanika.

Saputra, H. N. (2019). E-Book Berbasis Keterampilan Berpikir Kritis. Jurnaal Pendidikan Teknologi Informasi Dan Vokasional, 1(2), 21-28.

Saputri, A. E., \& Susilowibowo, J. (2020). Pengembangan Bahan Ajar E-Book pada Mata Pelajaran Praktikum Akuntansi Perusahaan Manufaktur. Jurnal Penelitian Pendidikan, 20(2), 154-162.

Sriwahyuni, I., Risdianto, E., \& Johan, H. (2019). PENGEMBANGAN BAHAN AJAR ELEKTRONIK MENGGUNAKAN FLIP PDF PROFESSIONAL PADA MATERI ALAT-ALAT OPTIK DI SMA. Jurnal Kumparan Fisika, 2(3), 145-152.

Sufairoh. (2016). Pendekatan Saintifik dan Model Pembelajaran. Jurnal Pendidikan Profesional, 5(3), $116-125$

Sugiyono. (2017). Metode Penelitian Kuantitatif, Kualitatif, dan RED. Alfabeta.

Susilana, R., \& Ihsan, H. (2014). Pendekatan Saintifik Dalam Implementasi Kurikulum 2013 Berdasarkan Kajian Teori Psikologi Belajar. Edutech, 13(2), 183-195. https://doi.org/10.17509/edutech.v13i2.3095

Trianto. (2015). Mendesain Model Pembelejaran Inovatif, Progresif, dan Kontekstual. Prenadamedia Group. Wiyanto. (2017). Pendekatan Saintifik pada Perkuliahan dengan Sistem E-Learning. Jurnal INTEGRALISTIK, 28(2), 217-229. https://doi.org/10.15294/integralistik.v28i2.13738 